\title{
(6) OPEN ACCESS \\ Common state mechanisms regulating tribal tobacco taxation and sales, the USA, 2015
}

\author{
Hillary DeLong, ${ }^{1}$ Jamie Chriqui, ${ }^{1,2}$ Julien Leider, ${ }^{1}$ Frank J Chaloupka ${ }^{1,3}$
}

${ }^{1}$ Health Policy Center, Institute for Health Research and Policy, University of Illinois at

Chicago, Chicago, Illinois, USA ${ }^{2}$ Division of Health Policy and Administration, School of Public Health, University of Illinois at Chicago, Chicago, Illinois, USA

${ }^{3}$ Department of Economics, University of Illinois at Chicago, Chicago, Illinois, USA

\section{Correspondence to}

Hillary DeLong, Health Policy Center, Institute for Health Research and Policy, 1747 W. Roosevelt Rd, Chicago, IL 60608, USA; hdelong@uic.edu

Received 29 March 2016 Revised 26 May 2016 Accepted 26 May 2016 Published Online First 27 June 2016

\section{CrossMark}

To cite: DeLong $\mathrm{H}$, Chriqui J, Leider J, et al. Tob Control 2016:25:i32-i37.

\section{ABSTRACT}

Background Native American tribes, as sovereign nations, are exempt from state tobacco excise taxation, and self-govern on-reservation activity in the USA. Under Federal law, state excise taxes are owed by nonmembers purchasing tobacco on tribal land, but states are limited in how they enforce or collect these taxes. This study highlights the various policy approaches that states have taken to regulate tobacco sales on tribal lands given jurisdictional challenges.

Methods State laws (statutes, regulations and case law), Attorney General opinions, and revenue notices and rulings effective as of 1 January 2015 for all 50 states and the District of Columbia were compiled using Boolean searches in Lexis-Nexis and Westlaw. Laws were limited to those addressing taxation compacts or tobacco sales involving tribal entities. Master Settlement Agreement laws and non-codified tribal codes/compacts were excluded.

Results Twenty of the 34 states with tribal lands address tribal tobacco sales. Fourteen states address intergovernmental compacts: 11 are tobacco specific, and suggest or require specific provisions. Fifteen states address tribal tax stamps: 2 explicitly prohibit stamping tribally sold products, 9 stamp all products, and 4 stamp some. Prepayment of excise tax is required in 12 states: 6 on all products, 4 on products in excess of quota, and 2 on products sold by non-tribal retailers. 6 states use quotas to limit tax-free tobacco available to tribes.

Conclusions Many states with a tribal presence have no formal strategies for non-members purchasing tobacco on tribal lands. Formalising policies and harmonising tax rates may assist states in collecting tax revenue from non-tribal consumers.

\section{INTRODUCTION}

Increasing the price of tobacco products is one of the most effective strategies in tobacco use prevention, ${ }^{1}$ but tobacco control efforts may be eroded where there are opportunities for tax avoidance and evasion. ${ }^{2}$ Tax avoidance/evasion are common where disparate tax rates occur in close proximity, ${ }^{3}$ and are especially detrimental when conflicting jurisdictions or interests make tax harmonisation or enforcement difficult. ${ }^{4}$ While all states tax cigarettes and most other tobacco products, ${ }^{5}$ their ability to enforce tax regulations on tribal lands often conflicts with a tribe's right to self-govern. In addition to the public health aims of tobacco taxation, tobacco excise tax revenues are a major source of income for state and tribal governments, and often help to fund tobacco control programming. ${ }^{6}$ The enforcement and collection of tax revenue generated on reservation is complicated by the issue of tribal sovereignty. Native American tribes, as sovereign nations within the USA, ${ }^{7}$ are exempt from state excise taxation, and have the power to govern their own lands, ${ }^{8}$ including on-reservation tobacco sales. ${ }^{9}$ Tribal tobacco sales are not limited to members of the tribe; anyone can purchase tobacco from tribal retailers, and they do. In one example in New Mexico, more than a quarter of smokers $(27.42 \%)$ reported purchasing cigarettes from tribal retailers in 2010-2011. ${ }^{3} 10$ The funds generated from tobacco sales on reservation lands are often used in many of the same ways as state tax revenue, such as funding education, roads, public health initiatives, public safety and infrastructure. $^{11}$

While any consumer can purchase tobacco on tribal land, only tribal members are exempt from state excise taxation, and tribes are obligated to apply state excise taxes to purchases made by all other consumers. ${ }^{9}$ However, state enforcement of this obligation on tribal lands can prove challenging; while Federal law requires remittance of those taxes to the state, a state cannot force a tribe to do so where it refuses. ${ }^{12}$ Additionally, courts have limited a state's ability to enforce tax collection or remittance against tribes, directing states to pursue alternative solutions, such as precollecting tax at the wholesale level, or establishing intergovernmental compacts. ${ }^{13}{ }^{14}$ States also face challenges from tribes in the courtroom and on the ground. Seneca Nation's efforts to protect its sovereignty in the face of New York's attempted regulation of tribal sales to non-tribal consumers led to multiple court challenges, and violent protests. ${ }^{15}$

As per the nature of tribal sovereignty, states do not have jurisdiction on tribal lands, and are unable to use the court system to pursue back taxes. These jurisdictional and remuneration issues, coupled with a stratified tax obligation, where some consumers are tax-exempt while others are not, can make state collection of taxes owed for tobacco sales to nontribal consumers difficult. Lost revenue can add up quickly. In 2000, cartons of cigarettes purchased on reservations in Washington retailed about $\$ 10$ less than off-reservation prices, and an $\sim \$ 80$ million dollars tobacco tax revenue loss was attributed to those purchases. ${ }^{16}$ This trend has only continued; in 2010-2011, Washington's on-reservation cigarettes were priced $\sim 65 \%$ lower than their offreservation counterparts, with almost $17 \%$ of smokers reporting making purchases on reservations. ${ }^{10}$ Tax harmonisation efforts become increasingly important when considering the sheer number of federally recognised tribes, and the states potentially impacted by lost tax revenue. There are currently 566 federally recognised tribes, and 34 states that contain tribal lands within their borders. ${ }^{17-19}$ 
In light of the complicated and ever-evolving nature of tribal tobacco sales, and the often competing economic and governance interests of the states and tribes, this study sought to determine the breadth and variety of state responses to tribal tobacco taxation needs, including common mechanisms and areas of regulatory response or concern. To our knowledge, while some studies have examined state-specific tribal tobacco regulation efforts, this issue has not been explored comprehensively across all states. Specifically, this study had three main aims: (1) to identify the types of regulatory mechanisms states are using to collect excise tax on tobacco sold on tribal lands to non-tribal consumers; (2) to analyse the nature of state-level regulatory response and (3) identify examples of comprehensive antievasion regulatory schemes at the state level.

\section{METHODS}

Relevant state laws effective as of 1 January 2015 were identified through Boolean keyword searches of primary legal research databases available through commercial legal research service providers, Lexis-Nexis and Westlaw. Searches were conducted for each of the 50 states and the District of Columbia (hereafter referred to as 'states') and were limited to each state's statutes (ie, bills enacted by state legislatures) and regulations, case law, Attorney's General opinions, and Department of Revenue notices/rulings. Focus was on laws that specifically related to taxation compacts (either general compact formation for any product or service, or tobacco-specific compacting parameters); as well as tobacco sales by/to tribal entities. State regulations related to tribal sales which were housed within a state's Master Settlement Agreement laws, a tribe's own laws or statetribal tax agreements not formalised as state law were excluded from collection. The Boolean search terms and priority topics were identified following a pilot study conducted using the laws from seven states of varying size, location and tribal presence and that were known to address tribal tobacco sales issues in their laws. A description of the categories of state laws and/or topics within the laws compiled for this study is provided in table 1 .

The legal research strategy was defined by the lead study author, was conducted by a law student, and the lead author provided a quality assurance review of the legal research compilation. All laws were then coded using a detailed coding tool by two independent coders (both attorneys). After the independent coding, the two coders met to conduct a final, consensus coding. The final coding was uploaded into a RedCap database. The data were then exported to STATA v. 10.1 for use in generating the descriptive data presented herein. For this study, specific focus was on generating dichotomous indicators of the variables defined in table 1.

\section{RESULTS}

As of 1 January 2015, 34 of the 50 states and the District of Columbia had tribal lands located within their borders; of those, only 20 had codified laws addressing the formation of tribal compacts or regulating tribal tobacco sales (hereafter 'tribal states') (see table 2). While 17 states had no tribal lands on which to sell tobacco, 14 states with tribal lands had no tribal-specific tobacco sales laws as defined by our study parameters.

Within the 20 tribal states, the two general categories of tax enforcement on tribal lands are compacts, which can legally dictate the behaviour on tribal land vis-à-vis contract law (14 states); and codified laws that function outside, or in lieu, of compacts (hereafter 'codified laws') which can only regulate offreservation behaviour (17 states). While 9 states use only one of these methods (3, compacts; 6, codified laws), 11 states use both methods in tandem.

\section{Compacts and intergovernmental agreements}

Of the 14 states that address compacts in some fashion, all but one (New York) suggests or requires the inclusion of specific provisions (see table 3). Unsurprisingly, the most common provisions include those pertaining to revenue collection, enforcement and compact duration. Additional provisions incorporate mechanisms frequently seen within a state's codified tax laws, and help bridge the two methods. These provisions address tax stamps (three states), record-keeping (three states) and tax rates (two states). Additional provisions only make sense in the context of separate but interconnected governments, including a waiver of sovereign immunity, and established refunds for tax prepayment (two states each).

\section{Codified laws}

While compact formation is the most commonly used strategy, three strategies within codified law are also widely used: tax stamps, tax prepayment on cigarettes sold to tribes and tax-free quotas (see table 2). Of those codified law strategies, the most common was the strategic use of tax stamps (15 states). While

Table 1 Description of select states' laws regulating cigarette sales on tribal reservation land_USA, 2015

\begin{tabular}{|c|c|}
\hline Type of law & Description \\
\hline Allotment of tax-free tribal tobacco & $\begin{array}{l}\text { State limits the amount of tax-free tobacco products sold to tribes using a quota or allotment system, typically calculated on tribal } \\
\text { population and national consumption figures. This also includes the use of a coupon or voucher system, where tribes provide } \\
\text { vouchers to distributors/wholesalers in exchange for tax-free cigarettes, and the state refunds wholesalers for taxes paid on } \\
\text { cigarettes purchased with vouchers. }\end{array}$ \\
\hline Codified laws & $\begin{array}{l}\text { State laws addressing tobacco taxation that, due to tribal sovereignty, generally only dictate behaviour off reservation. These laws } \\
\text { include mechanisms such as tax stamps, and can apply to non-tribal consumers making tobacco purchases on tribal lands, or } \\
\text { off-reservation tribal activity. Codified laws are those that have been formally adopted by a state legislature (statutory law) or } \\
\text { executive branch agency (administrative law or rules or regulations). }\end{array}$ \\
\hline Compact formation & $\begin{array}{l}\text { State addresses the formation of intergovernmental agreements between state and tribe(s), including general agreements that do } \\
\text { not pertain specifically to tobacco products. Compacts function as contracts between governments, and allow a state more flexibility } \\
\text { when enforcing its tax laws on non-members making purchases on tribal lands. The existence of codified compact formation } \\
\text { guidance does not necessarily indicate a state's actual and current use of intergovernmental agreements. }\end{array}$ \\
\hline $\begin{array}{l}\text { On-reservation tax stamp usage } \\
\text { addressed }\end{array}$ & $\begin{array}{l}\text { State addresses the use of tobacco excise tax stamps for products sold on reservation, including those states that explicitly prohibit } \\
\text { stamping. These laws also dictate which products sold on reservation (if any) require tax stamps. }\end{array}$ \\
\hline $\begin{array}{l}\text { Products for which tribe prepays state } \\
\text { excise tax }\end{array}$ & $\begin{array}{l}\text { State requires tribes to prepay excise tax on cigarettes, typically refunding tribes for cigarettes purchased by tax-exempt consumers. } \\
\text { This includes laws specifying which cigarette products, if any, require prepayment. }\end{array}$ \\
\hline
\end{tabular}


Table 2 States' laws regulating cigarette sales on tribal reservation land-USA, 1 January 2015

\begin{tabular}{|c|c|c|c|c|c|}
\hline \multirow[b]{2}{*}{ State $(\mathrm{N}=20)$} & \multicolumn{2}{|c|}{ Types of tribal sales regulation } & \multicolumn{3}{|c|}{ Tax enforcement strategies implemented through codified law } \\
\hline & Compact formation & Codified laws & $\begin{array}{l}\text { On-reservation use of } \\
\text { tax stamps addressed }\end{array}$ & $\begin{array}{l}\text { Allotment of tax-free } \\
\text { tribal tobacco }\end{array}$ & $\begin{array}{l}\text { Products for which tribe prepays } \\
\text { state excise tax }\end{array}$ \\
\hline Alaska & & Yes & $一^{*}$ & & \\
\hline Arizona & & Yes & All & Yes & Other \% \\
\hline Florida & Yes & Yes & All & Yest & Excess \\
\hline Idaho & & Yes & Some & & Other^ \\
\hline lowa & Yes & Yes & Prohibited§ & & All \\
\hline Michigan & Yes & & - $^{*}$ & & \\
\hline Minnesota & Yes & Yes & Some $\neq$ ף & Yes & Excess \\
\hline Montana & Yes & Yes & Someף & Yes & All \\
\hline Nebraska & Yes & Yes & All & & All \\
\hline Nevada & & Yes & All & & All \\
\hline New Mexico & Yes & Yes & All & & \\
\hline New York & Yes & Yes & All & Yest & Excess \\
\hline North Dakota & & Yes & - ${ }^{* *}$ & & \\
\hline Oklahoma & Yes & Yes & All & Yes & Excess \\
\hline Oregon & Yes & & - $^{*}$ & & \\
\hline South Dakota & Yes & & - $^{*}$ & & \\
\hline Utah & & Yes & Someł & & All \\
\hline Washington & Yes & Yes & All & & \\
\hline Wisconsin & Yes & Yes & All & & All \\
\hline Wyoming & Yes & Yes & Prohibited§ & & \\
\hline Totals & 14 & 17 & 15 & 6 & 12 \\
\hline \multicolumn{6}{|c|}{$\begin{array}{l}\text { Yes-State law explicitly requires usage of regulation. } \\
\text { Prohibited-State law requires tax stamps on cigarettes sold off reservation, but explicitly prohibits the use of tax stamps on products sold on reservation. } \\
\text { Excess-State requires prepayment of state taxes on all products sold in excess of a predetermined tax-free allotment. } \\
\text { Other\%—State requires prepayment of state taxes on all products sold to non-members. } \\
\text { Other^—State requires prepayment of state taxes on all products sold on reservation by non-tribal retailers. } \\
\text { All-State law applies to all products sold on reservation. } \\
\text { Some-In certain instances (eg, products sold to non-members or products sold to tribes without tax agreements), cigarettes or tobacco products sold on reservation require stamps. } \\
{ }^{*} \text { State regulates tribal tobacco sales and uses tobacco stamps, but is silent on stamping products sold on reservation. } \\
\text { tEnforced with a voucher or coupon system. } \\
\text { ‡Tax stamps required on products sold to non-members. } \\
\text { §Stamps explicitly prohibited on cigarettes or tobacco products sold on reservation. } \\
\text { १Tax stamps required on products sold to tribes without agreements. } \\
{ }^{* *} \text { State does not use tobacco tax stamps for any products sold within the state. }\end{array}$} \\
\hline
\end{tabular}

two states (Iowa and Wyoming) explicitly prohibit the stamping of tribally sold products (compared to the stamping of products sold off reservation, which is required), the remaining 13 states use tax stamps on some or all of the products sold on reservation. The second most common strategy is tax prepayment (12 states), of which six require tax prepayment on all cigarettes sold to tribes, offering predetermined refunds to account for taxes paid on cigarettes presumably sold to tax-exempt members. Four states require prepayment of taxes on any cigarettes sold in excess of their respective statutory tax-free allotments. The remaining two states require prepayment of any products sold on reservation by non-tribal retailers. Tax-free quotas (or allotments) are the third most common strategy of regulation (six states), two of which use a coupon or voucher system as an enforcement mechanism.

\section{DISCUSSION}

To our knowledge, this was the first study to examine the types of state laws pertaining to tobacco sales on tribal lands. While 34 states have a tribal presence, ${ }^{17-19}$ only 20 of these states $(58.8 \%)$ address tribal tobacco tax collection; the remaining 14 states with a tribal presence $(41.2 \%)$ do not have mechanisms in place to ease the collection of excise tax on tribal lands for tobacco sales made to non-members. This is particularly of interest given the steady increase in state tobacco taxes meant, in part, to reduce tobacco consumption. ${ }^{5}$ Failing to address tribal sales to non-members could undermine these tobacco control efforts, as tax avoidance and evasion opportunities could increase where a state is unable to enforce the application of excise tax to certain sales, resulting in disparate cigarette prices.

Within the 34 states with a tribal presence, opportunities exist to create (or expand present) tobacco sales laws to ease tax law enforcement on and off reservation. The practical result of tribal sales to non-members is a complete shift of the economic incidence of the tribe's tax break to consumers, ${ }^{20}$ resulting in sometimes significant price differentials, and a potential loss of state revenue. To address potential jurisdictional conflict or tax revenue loss in states with tribal presence, tribal states have developed strategies for tax enforcement and collection, often combining them to form a more comprehensive regulatory scheme. In general, two strategies exist: regulating the actual sales of tobacco on tribal lands through the use of intergovernmental compacts, and minimising the availability of tax-free cigarettes within the distribution process using codified law.

Compacts, which allow states and tribes to avoid certain complications inherent in tribal sovereignty by functioning within the bounds of contract law, are the most popular means of addressing tribal tobacco sales to non-members. These compacts, typically negotiated between state and tribal officials, can allow both parties to protect their interests in tax revenue and 
Table 3 Compact states with suggested or required compact provisions-USA, 1 January 2015

\begin{tabular}{|c|c|c|c|c|c|c|c|c|c|}
\hline \multirow[b]{2}{*}{$\begin{array}{l}\text { State } \\
(\mathrm{N}=14)\end{array}$} & \multicolumn{9}{|c|}{ Compact provision types } \\
\hline & $\begin{array}{l}\text { Revenue collection/ } \\
\text { sharing }\end{array}$ & Enforcement & $\begin{array}{l}\text { Duration/renewal } \\
\text { period (years) }\end{array}$ & $\begin{array}{l}\text { Distribution } \\
\text { of funds }\end{array}$ & $\begin{array}{l}\text { Tax } \\
\text { stamps }\end{array}$ & Record-keeping & $\begin{array}{l}\text { Tax } \\
\text { Rate }\end{array}$ & $\begin{array}{l}\text { Waiver of } \\
\text { sovereign } \\
\text { Immunity }\end{array}$ & $\begin{array}{l}\text { Refund } \\
\text { amount }\end{array}$ \\
\hline Florida & Yes & & & & & & & & \\
\hline lowa* & Yes & & & Yes & & & & & \\
\hline Michigan & Yes & Yes & Regular (2) & & & & & Yes & \\
\hline Minnesota & Yes & & & & & & & & Yes \\
\hline Montana* & Yes & & $\mathrm{N} / \mathrm{S}$ & Yes & & & & & \\
\hline Nebraska & Yes & Yes & $\mathrm{N} / \mathrm{S}$ & Yes & Yes & & & Yes & \\
\hline $\begin{array}{l}\text { New } \\
\text { Mexico* }\end{array}$ & Yes & Yes & & & & & & & \\
\hline New York & Uses compacts, but do & s not suggest or & require compact prov & within its codi & ed laws. & & & & \\
\hline Oklahoma & Yes & Yes & & & Yes & Yes & Yes & & \\
\hline Oregon & & Yes & & & & & & & \\
\hline South Dakota & Yes & & Regular (5) & & & & & & \\
\hline Washingtont & Yes & Yes & Regular (8) & Yes & Yes & Yes & Yes & & \\
\hline Wisconsin & & & & & & & & & Yes \\
\hline Wyoming & Yes & & Regular (1) & & & Yes & & & \\
\hline Totals & 11 & 6 & 6 & 4 & 3 & 3 & 2 & 2 & 2 \\
\hline
\end{tabular}

self-governance. Compacts can be especially effective strategies where tribal lands are pervasive, and within close proximity to large populations. In Oklahoma, where tribal retailers are interspersed among non-tribal retailers, rather than limited to specific tribal lands, the percentage of consumers purchasing from tribal retailers was relatively high $(31.28 \%) .{ }^{3}{ }^{10}$ Following the Supreme Court's decision in Citizen Band Potawatomi in $1991,{ }^{13}$ the state began using compacts with several tribes in an attempt to curb its jurisdictional challenges. The state successfully negotiated several rounds of compacts, slowly increasing tribal tax rates to meet state levels, and affording refunds to account for sales to tax-exempt parties. ${ }^{21} 22$ One result of these new compacts has been a diminishment in the number of tobacco purchases made at tribal smokeshops. ${ }^{22}$ The laws dictating compact provisions establish tax rates; uniquely, it is the only tribal state that addresses the use of border zones (establishing different tax rates for tribal retailers located near Kansas or Missouri). ${ }^{23}$ While the inclusion of provision suggestions or requirements does not necessarily dictate the actual content of negotiated compacts, it can provide consistency in states with multiple tribes, and can ensure that key provisions are addressed across all future negotiations. The state of Washington has established that all tobacco compacts contain tobacco control elements, prohibiting tribes from using tobacco tax-derived revenue to subsidise cigarette retailers. ${ }^{24}$ Similar provisions directing revenue towards tobacco control efforts on reservation could bolster a state's public health initiatives among a population with the nation's highest smoking rate $(29.2 \%) .^{25}$

While compacts are popular, negotiating them can be time and cost intensive, ${ }^{12} 21$ and they can be difficult to use or enforce where the state-tribe relationship is fractured (eg, New York). ${ }^{15}{ }^{26}$ As such, the use of codified laws that seek to reduce the amount of tax-free cigarettes available to tribes are a popular method of tobacco sales regulation, as they function to reduce the availability of tax-free cigarettes in the tribal marketplace. One popular method of reduction is through tax prepayment. Almost two-thirds of tribal states require tax prepayment, where a state precollects taxes owed on cigarettes at a point within the distribution process prior to ultimate sale. This is often done through the use of tax stamps, but can be done even where tax stamps are not used, or where purchasing parties may be tax exempt in limited circumstances.

One way that tax prepayment functions within tribal distribution is through tax-free quotas (also termed 'allotments'). These quotas, established formulaically, are typically based on tribal member population and national or tribal consumption habits; ${ }^{27-30}$ establish the amount of tax-free cigarettes tribes may purchase, and represent a presumed number of packs that a tribe will sell to its tax-exempt members. While these quotas are meant to provide tribes with enough cigarettes for personal consumption, quota formulas often result in overstated estimates, resulting in an excess of tax-exempt cigarettes in the marketplace. ${ }^{3}$ How quotas function on a practical level differ across states. Purchases made above and beyond the quota in Florida, Minnesota, New York and Oklahoma require tax payment in full, regardless of a tribe's tax-exempt status. In Montana, taxes are prepaid on all cigarettes, and refunds are given based on established quotas. In Arizona, a similar strategy limits a tribe's access to tax-free cigarettes via quota, and requires tax prepayment on cigarettes sold to non-members. In theory, these quotas limit the amount of tax-free packages available to non-members, and are generally enforced with record-keeping. In two states (Florida and New York), quotas are further enforced with vouchers or coupons, which are given to distributors in exchange for tax-free cigarettes. As distributors must apply tax stamps prior to sale, they are able to redeem those vouchers for refunds from the state for taxes paid on stamped packs.

The effectiveness of prepayment can depend on how it is implemented, and many states (including those that apply quotas) use tax stamps as a method of enforcement. Some states 
(such as Iowa and Wyoming) explicitly prohibit the stamping of cigarettes sold on tribal lands as a means of differentiating tribal sales from non-tribal sales, while others limit stamps to certain products. Nine states apply some form of tax stamp to all tribal products. In Utah and Idaho, stamps are applied to products intended for sale to non-members. Minnesota, in addition to stamping cigarettes intended for non-members, also stamps all products sold to tribes without intergovernmental agreements. In an attempt to differentiate products sold on reservation, some states use stamps that differ in appearance from those applied to products sold off reservation. These stamps can be used across all tribes within a state, or be specific to an individual tribe. ${ }^{31}$

Similar to prepayment, tax stamps are only as effective as their implementation. Strategic application within the distribution chain is important. Tobacco has become a popular source of income for tribes, and the number of tribal manufacturers has increased steadily, ${ }^{32}$ in part, as a response to state regulatory efforts to curb evasion. In 2010, as a means to address the loss of $\sim 500000$ in state income a day to sales on tribal lands, ${ }^{26}$ New York adjusted its implementation, and began requiring that all cigarettes receive tax stamps prior to shipment to tribal distributors, reducing the opportunity for tribal distributors to opt out of state tax collection. ${ }^{12} 33{ }^{34}$ In response, tribes increased their manufacturing efforts; cigarettes manufactured on-reservation bypassed stamping agents, and allowed tribes to sell them untaxed. ${ }^{35}$ Despite alternative efforts to source tax-free tobacco by the tribes, the presence of stamp-free tobacco packages (typical of preimplementation, on-reservation purchases) and tribally manufactured cigarette packages in New York has declined significantly post-2010 implementation, suggesting a shift away from on-reservation tobacco purchases by non-tribal consumers. ${ }^{36}$

While this study provides a comprehensive look at codified state policies addressing tribal tobacco sales, it was limited in several ways. First, our study excluded the collection and analysis of compacts, which are generally not incorporated into official state statutory (legislative) or administrative (regulatory) law, as their terms are regularly renewed and negotiated, and do not require codification to be binding for either the tribes or the state. As such, our study is limited to only those compacts that were codified into state law, and does not reflect the content of noncodified compacts that may exist. Future studies should explore the existence and content of these non-codified compacts. Second, nuances or gaps in implementation or enforcements efforts, which are often established at the agency level (ie, state departments of revenue), were not captured unless they were included within a state's codified law, official agency rulings or case law. Even with these limitations, this study provides important insight into tribal taxation mechanisms that can aid in states in their tobacco control efforts, and limit revenue loss due to evasion.

Each state has its own unique challenges; while there is no single best approach, it holds true that price differentials across state-tribal borders are among the primary incentives for tobacco tax avoidance and evasion. ${ }^{3}$ In that sense, comprehensive approaches to tribal tobacco sales regulations are crucial to curbing evasion and avoidance, and reducing consumption rates. Tax harmonisation, which can be implemented through the use of taxation agreements; and changes in distributor regulations, including the implementation of tax stamps at strategic points along the supply chain, could lessen price differentials and aid in the reduction of tax avoidance and evasion. ${ }^{3}$

\section{CONCLUSION}

A broader look at the variety of strategies implemented presents an interesting (albeit somewhat incomplete) understanding of potential impact, and only highlights the importance of tailored and nuanced policy implementation. Many of the regulatory mechanisms discussed can and are used in tandem. Nuanced tax stamping procedures, including application early within the distribution chain, and limitations on resale; combined with tax prepayment or quotas can reduce the general population's access to tax-free cigarettes, while still respecting tribal sovereignty. Additionally, compacts are a mechanism that can bolster additional regulatory efforts, and help to maintain positive relationships between state and tribe where jurisdictional issues may present issues with enforcement. While some states continue to establish or modify laws pertaining to tribal tobacco sales, many still have no formal structure for addressing tax collection from non-members purchasing product on tribal lands. Formalising taxation policies as they relate to non-tax-exempt sales on tribal lands, and the creation of enforcement or precollection strategies, may assist states in collecting revenue otherwise lost.

\section{What this paper adds}

- While the Federal government requires tribes to collect tax on tobacco products sold on reservation to non-members, state governments do not have the authority to enforce that collection on tribal lands, and revenue loss can occur where tribes choose not to remit tax revenue to the state.

- States use a variety of policies to address jurisdictional challenges present in the enforcement and collection of excise taxes for on-reservation tobacco sales, including tax stamps and intergovernmental tax agreements.

- These policies address distribution both on and off reservation, and minimise the availability of tax-free cigarettes to non-tribal members.

- Many states use compacts to work with tribes on jurisdictional conflicts, and have suggested or required provisions that help to establish consistent policies across tax agreements.

- Implementation gaps can lessen the impact of tax stamps or prepayment, particularly with the rise of tribally manufactured cigarettes.

Twitter Follow Tobacconomics at @tobacconomics, and Jamie Chriqui at @jfchriqui Acknowledgements The authors would like to thank Camille Gourdet, JD, MA, for her assistance in the collection and coding of these laws, and Colin Goodman, JD, for his research assistance. Funding was provided by the National Cancer Institute under the State and Community Tobacco Control Initiative, grant number U01-CA154248, University of Illinois; Frank Joseph Chaloupka, PhD, Principal Investigator. The views presented herein are solely those of the authors and are not, necessarily, the views or opinions of the National Cancer Institute or the authors employer.

Contributors HRD conceptualised and designed the study, led the research, and drafted the manuscript. JFC contributed substantively to the manuscript's conceptualisation. She additionally provided critical feedback on the drafted manuscript. JL contributed to the descriptive data generation. FJC contributed to the manuscript's conceptualisation and provided critical feedback on the manuscript. He is the principal Investigator for this funded study.

Funding National Cancer Institute, 10.13039/100000054, U01-CA154248.

Competing interests None declared.

Provenance and peer review Not commissioned; externally peer reviewed.

Data sharing statement State data, as well as the data collection tool and coding guidance, will be posted to the Tobacconomics.org website. 
Open Access This is an Open Access article distributed in accordance with the Creative Commons Attribution Non Commercial (CC BY-NC 4.0) license, which permits others to distribute, remix, adapt, build upon this work non-commercially, and license their derivative works on different terms, provided the original work is properly cited and the use is non-commercial. See: http://creativecommons.org/ licenses/by-nc/4.0/

\section{REFERENCES}

1 Chaloupka FJ, Yurkeli AA, Fong GT. Tobacco taxes as a tobacco control strategy. Tob Control 2012;21:172-80.

2 Joossens L, Raw M. From Cigarette Smuggling to Illicit Tobacco Trade. Tob Control 2012:21:230-4.

3 Chaloupka FJ, Edwards S, Ross $\mathrm{H}$, et al. Preventing and reducing illicit tobacco trade in the United States. Centers for Disease Control and Prevention, 2015. http:// tobacconomics.org/wp-content/uploads/2015/12/Chaloupka_CDC_Illicit_Trade_US_ 12-21-15.pdf (accessed Mar 2016).

4 World Health Organization. Technical manual on tobacco tax administration. Geneva, 2010.

5 Gourdet CK, Chriqui JF, Leider J, et al. Tobacco product taxation: an analysis of state tax schemes nationwide, selected years, 2005-2014. Prepared for Tobacconomics, Health Policy Center, Institute for Health Research and Policy, University of Illinois at Chicago, 2015.

6 Centers for Disease Control and Prevention. Best Practices for Comprehensive Tobacco Control Programs. 2014. http://www.cdc.gov/tobacco/stateandcommunity/ best_practices/index.htm (accessed 7 Mar 2016).

7 Worcester v. Georgia, 31 U.S. 515 (1832)

8 Williams v. Lee, 358 U.S. 217, 220 (1959).

9 Oklahoma Tax Com'n v. Chickasaw Nation, 515 U.S. 450 (1995).

10 US Department of Commerce, Census Bureau (2015). National Cancer Institute-sponsored Tobacco Use Supplement to the Current Population Survey (May 2010-2011): http://thedataweb.rm.census.gov/ftp/cps_ftp.html\#cpssupps. Data files and technical documentation.

11 Zelio J. Piecing together the state-tribal tax puzzle. National Conference of State Legislatures. 2005. http://www.ncsl.org/issues-research/tribal/state-tribal-relationspublications.aspx\#PS (accessed 10 Mar 2015).

12 Samuel K, Ribisl KM, Williams RS. Internet cigarette sales and native American Sovereignty: political and public health contexts. J Public Health Policy 2012;33:173-87.

13 Okla. Tax Commission v. Citizen Band, Potawatomi Indian Tribe of Okla., 498 U.S. 505 (1991).

14 Moe v. Confederated Salish and Kootenai Tribes of the Flathead Reservation et al. 425 US 463 (1976).

15 Associated Press. Ruling Clears New York State to Tax Tribes' Cigarette Sales. New York Times 2011. http://www.nytimes.com/2011/05/10/nyregion/ ruling-clears-new-york-to-tax-tribes-cigarette-sales.html (accessed 29 Feb 2016).

16 Stehr M. Cigarette tax avoidance and evasion. J Health Econ 2004;24277-97. http://www.sciencedirect.com/science/article/pii/S0167629604001225 (accessed 23 Apr 2015)
17 Bureau of Indian Affairs. Indian entities recognized and eligible to receive services from the United States Bureau of Indian Affairs. Fedl Reg 2015;80. http://www.bia. gov/cs/groups/webteam/documents/document/idc1-029026.pdf (accessed Feb 2016).

18 National Park Service. Indian Reservations in the Continental United States. Date Unknown. http://www.nps.gov/nagpra/DOCUMENTS/ResMAP.HTM (accessed 23 Mar 2016).

19 Bureau of Indian Affairs. Tribal Leaders Directory. Fall/Winter. 2015. http://www.bia. gov/cs/groups/xois/documents/document/idc1-028053.pdf (accessed 23 Mar 2016).

20 DeCicca P, Kenkel DS, Liu F. Reservation Prices: an Economic Analysis of Cigarette Purchases on Indian Reservations. National Bureau of Economic Research Working Paper Series 2014;No. 20778. http://www.nber.org/papers/w20778.pdf (accessed Nov 2015).

21 Laux F, Buckskin S. An Oklahoma history of cigarette taxation. Prepared for Oklahoma Tobacco Research Center, Stephenson Cancer Center, University of Oklahoma and Tobacconomics, Health Policy Center, Institute for Health Research and Policy, University of Illinois at Chicago, 2015.

22 Chaloupka F, Huang J, Laux F. A significant cigarette tax rate increase in Oklahoma would produce a large, sustained increase in state tobacco tax revenues. Prepared for Tobacconomics, Institute for Health Research and Policy, University of Illinois at Chicago, 2016

23 Okla. Admin. Code 710:70-7-8 (2015).

24 Rev. Code Wash. (ARCW) § 43.06 .455 (2015).

25 Jamal A, Homa DM, O'Connor E, et al. Current cigarette smoking among adults — United States, 2005-2014. MMWR Morb Mortal Wkly Rep 2015; 64:1233-40.

26 Gralla J. New York wins ruling in tribal cigarette tax clash. Reuters. 9 May 2011. http://www.reuters.com/article/newyork-tobacco-idUSN0924451920110509 (accessed 20 Feb 2016).

27 N.Y. Tax § 471-e (2015).

28 Fla. Stat. Ann. § 210.1801 (2015).

2968 Okl. Stat. Ann. § 349.1 (2015).

30 Mont. Code Ann. § 16-11-155 (2015)

31 Chriqui JF, DeLong H, Gourdet C, et al., Centers for Disease Control and Prevention (CDC). Use of tobacco tax stamps to prevent and reduce illicit tobacco tradeUnited States, 2014. MMWR Morb Mortal Wkly Rep 2015;64;541-6.

32 Bondaryk M, Okamoto J, Henderson PN, et al. Master settlement agreement compliance tobacco directories: a tool to track tribally manufactured cigarettes. Nicotine Tob Res 2016;18:1311-14.

33 Kurti M, von Lampe K, Johnson J. The intended and unintended consequences of a legal measure to cut the flow of illegal cigarettes into New York City: the case of the South Bronx. Am J Public Health 2015;105:750-6.

34 Oneida Nation of NY v. Cuomo, 645 F3d 154 (2nd Cir. 2011).

35 Kaplan T. In Tax Fight, Tribes Make, and Sell, Cigarettes. New York Times 22 Feb 2012. http://www.nytimes.com/2012/02/23/nyregion/indian-tribes-make-owncigarettes-to-avoid-ny-tax.html?_r=0 (accessed 22 Feb 2016).

36 National Research Council. Understanding the U.S. Illicit tobacco market: characteristics, policy context, and lessons from international experiences. Washington DC: The National Academies Press, 2015. 